\section{Massive and painful ascites as a presenting manifestation of systemic lupus erythematosus flare: a case report and literature review}

\author{
LEI ZHOU ${ }^{1}$, CHEN MING SUN ${ }^{1}$, WEN LI CHEN ${ }^{2}$, \\ HENG ZHANG ${ }^{1}$, PING WANG ${ }^{1}$, JIE WU $^{1}$
}

\begin{abstract}
Lupus peritonitis $(L P)$ is extremely rare. Acute LP is characterized by rapid onset of ascites and severe abdominal pain, in addition to other well-recognized clinical features of a general systemic lupus erythematosus (SLE) flare. Ascites associated with acute LP has been rarely reported as the prominent feature of a SLE flare. We report a 39-year-old woman who developed massive, painful ascites as the presenting manifestation of a SLE flare. Diagnostic workup ruled out the possibility of hepatic, cardiovascular, infectious, or malignant diseases, and confirmed the presence of a SLE flare. The patient was treated with methyl prednisolone and hydroxychloroquine resulting in dramatic improvement of her condition. During ambulatory follow up, she has remained asymptomatic up to the moment of this writing. Adrenal steroids and hydrocychloroquine may be useful for the management of SLE flares in patients with massive, painful ascites due to acute LP.
\end{abstract}

(Rev Med Chile 2014; 142: 255-260).

Key words: Lupus erythematosus, systemic; Ascites; Peritonitis.

\section{Ascitis dolorosa y masiva como forma de presentación de una reactivación lúpica. Presentación de un caso}

La peritonitis lúpica es rara. El cuadro agudo se caracteriza por ascitis de comienzo rápido, dolor abdominal severo y otras manifestaciones de una recidiva de un lupus eritematoso sistémico (LES). Sólo ocasionalmente e ha informado que la ascitis y peritonitis lúpica sean las principales manifestaciones de una recidiva lúpica. Presentamos a una mujer de 39 años que presentó ascitis masiva y dolorosa como la primera manifestación de una reactivación lúpica. El estudio diagnóstico descartó problemas hepáticos, pulmonares, cardiacos, cáncer o infecciones y confirmó la reactivación lúpica. La paciente se trató con metilprednisolona $y$ cloroquina, resultando en una mejoría dramática. Al momento de preparar este informe, la paciente permanece asintomática en control ambulatorio. Los corticoides y cloroquina pueden ser medicamentos útiles para el tratamiento de pacientes con ascitis dolorosa y masiva secundaria a peritonitis lúpica.
'Department of Gastroenterology, The Central Hospital of Wuhan, Tongji.

Medical College, Huazhong University of Science and Technology, Wuhan, Hubei, P.R. China.

2Department of Rheumatology and Nephrology, The Central Hospital of Wuhan, Tongji Medical College, Huazhong University of Science and Technology, Wuhan, Hubei, P.R. China.

Sources of support: This work was not funded by any source. Conflict of Interest: There was no potential conflicts of interest.

Recibido el 1 de abril de 2013, aceptado el 20 de enero de 2014.

Correspondence: Jie Wu, MD. Department of Gastroenterology, The Central Hospital of Wuhan, Tongji Medical College, Huazhong University of Science and Technology, Shengli Street, Jiangan District, Wuhan, Hubei, P.R. China.

Phone: +862782211566 .

Fax: +862788187719 .

wujie12375@yahoo.cn 
S erositis is commonly seen in patients with systemic lupus erythematosus (SLE). While pleural or pericardial involvement is common, peritoneal involvement is relatively rare ${ }^{1,2}$. The lifetime prevalence of lupus peritonitis (LP) in a SLE patient is about $8-11 \%{ }^{3}$.

LP may be acute or chronic and it usually does not produce massive ascites. Ascites due to acute LP typically is of rapid onset, is associated with severe abdominal pain and occurs during disease flares $^{3}$. It has been rarely reported as the presenting manifestation of SLE.

We herein report a patient with a SLE flare who presented with massive and painful ascites.

\section{Case report}

On September 2011, a SLE was diagnosed in a 39-year-old woman when she presented with fever, joint pain, malar rash and positive serology. She was treated successfully with adrenal steroids. Prednisone was gradually tapered to less than $10 \mathrm{mg}$ daily and the patient had no clinical or laboratory findings of active disease until August 2012. In September 2012 she voluntarily discontinued prednisone therapy. She was admitted to our hospital on october 13, 2012 because of progressive abdominal distension with pain, lasting 20 days. On physical examination she was afebrile, with a pulse rate of $100 / \mathrm{min}$, a respiratory rate of $21 / \mathrm{min}$ and blood pressure of 131/100 mmHg. Heart sounds were normal, and there was no sign of heart failure or tamponade. Her abdomen was distended and diffusely tender, without palpable masses or organomegaly. Signs of ascites were present. She also had bilateral pleural effusion. Cardiovascular, nervous and musculoskeletal system examination was normal.

Laboratory showed an erythrocyte count of $5.66 \times 10^{12} / \mathrm{L}$, a platelet count of $236 \times 10^{9} / \mathrm{L}$, a total leukocyte count of $6.56 \times 10^{9} / \mathrm{L}$, a neutrophil count of $5.38 \times 10^{9} / \mathrm{L}$, a lymphocyte count of $0.71 \times 10^{9} / \mathrm{L}$, with $81.98 \%$ neutrophils and $10.88 \%$ lymphocytes. Urine examination showed occult blood $(++)$, protein $(+)$ and no cellular casts. Biochemical evaluation revealed a serum albumin at $32.1 \mathrm{~g} / \mathrm{L}$, liver function tests, creatinine kinase, amylase, lipase, creatinine, blood urea nitrogen and electrolytes were normal. Erythrocyte sedimentation rate was $2 \mathrm{~mm} / \mathrm{h}$ and $\mathrm{C}$ reactive protein was $1.01 \mathrm{mg} / \mathrm{dL}$. D-dimer, prothrombin time, and partial thromboplastin were normal. Serum levels of tumor markers were normal, but CA 125 was markedly increased at $133.8 \mathrm{U} /$ $\mathrm{mL}$ (normal: $0 \sim 35 \mathrm{U} / \mathrm{mL}$ ). Serum anti-tuberculosis antibody was negative. PPD skin test was negative. A peritoneal tap was performed, yielding ascites with characteristics of exudate (Table 1).

Table 1. Laboratory findings of peritoneal and pleural fluids

\begin{tabular}{|lll|}
\hline Variables & Peritoneal fluid & Pleural fluid \\
Appearance & Yellow & Yellow \\
Transparency & Transparent & Mildly muddy \\
Rivalta test & Weakly positive & Weakly positive \\
\hline Protein (g/L) & 45.3 & 36.1 \\
Glucose (mmol/L) & 5.9 & 6.16 \\
LDH (U/L) & 276 & 173 \\
Effusion-serum protein proportion & 0.71 & 0.56 \\
Effusion-serum LDH proportion & 0.94 & 0.59 \\
CEA (ng/mL) & $<0.5$ & $<0.5$ \\
ADA (U/L) & $<50$ & $<50$ \\
Nucleated cell count $\left(\times 10^{6} / \mathrm{L}\right)$ & 200 & 100 \\
Cell classification & Lymphocytes prevailed with a few meso- & Lymphocytes prevailed with a few meso- \\
& thelial cells & thelial cells \\
Cytology & There were neutrophils, lymphocytes and & There were neutrophils, lymphocytes and \\
Cultures for bacteria and tubercle & mesothelial cells, but no tumor cells & mesothelial cells, but no tumor cells \\
\hline bacillus & Negative & Negative \\
\hline
\end{tabular}


Massive and painful ascites in systemic lupus erythematosus - L. Zhou et al

Echocardiography revealed a normal pericardium, no pericardial effusion and normal ejection fraction. A plain abdominal X-ray did not show clear free gas and gas-fluid levels. Abdominal CT scanning showed massive ascites with no organomegaly or space occupying lesions and enlarged lymph nodes on October 15 (Figure 1A). CT angiography did not show obvious superior or inferior mesenteric artery stenosis or occlusion on October 15 (Figure 1B). Chest CT scanning showed bilateral pleural effusion and pulmonary infiltrates, without lymphadenopathy on October

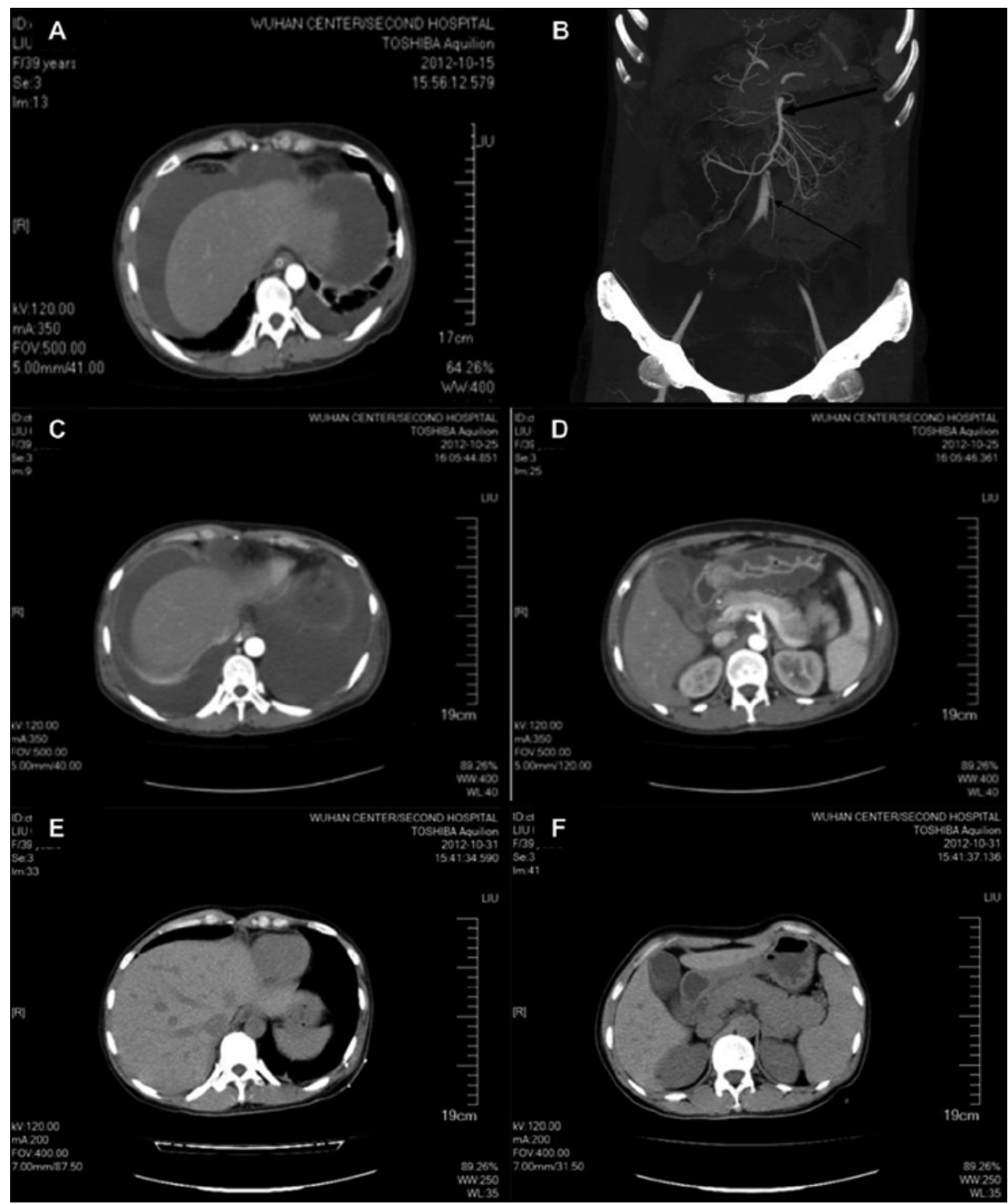

Figure 1. (A) Abdominal CT scan showed massive ascites on Oct 15. (B) Mesenteric artery angiography showed that superior or inferior mesenteric arteries had not obvious stenosis and occlusion on Oct 15. The thick black arrow shows the superior mesenteric artery; the thin black arrow shows the inferior mesenteric artery. (C-D) Abdominal CT scan showed significantly increased ascites (C), diffuse edema and thickening of bowel wall (D) on Oct 25. (E-F) Abdominal CT scan showed obviously improved ascites (E), and bowel wall edema and thickening (F) on Oct 31. 
16 (Figure 2A-B). The patient was treated with 0.5 $\mathrm{g} /$ day of ornidazole, $0.4 \mathrm{~g} /$ day of ciprofloxacin and $3 \mathrm{~g} /$ day of cefoperazone/sulbactam during seven days after obtaining bacterial culture specimens from her blood, throat and ascitic fluid. However, she experienced nausea and vomiting, her abdominal distension and pain did not subside, and ascites increased. A new chest CT on October 22 showed an aggravation of pleural effusion and pulmonary infiltrates (Fig 2C-D). A new abdominal CT on October 25 showed significantly increased ascites, diffuse edema and thickening of bowel wall (Figure 1C-D).

Further investigations showed markedly increased serum anti-nuclear antibodies (ANA) at $800 \mathrm{U} / \mathrm{mL}$ (normal: $0 \sim 12 \mathrm{U} / \mathrm{mL}$ ). The anti-
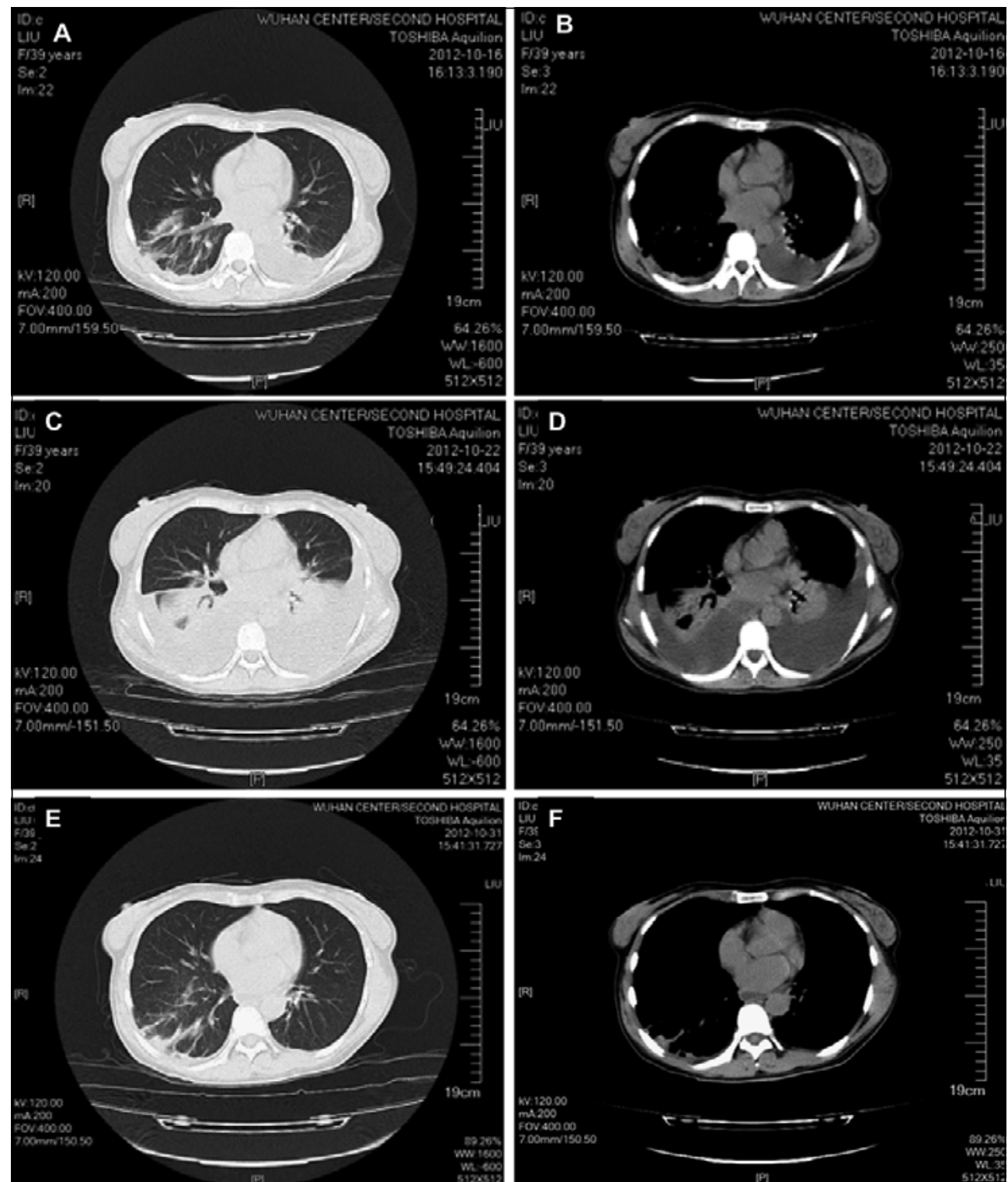

Figure 2. (A-B) Chest $C T$ scan showed bilateral pleural effusion and pulmonary infiltrates on Oct 16. (C-D) Chest CT scan showed obviously aggravated pleural effusion and pulmonary infiltrates on Oct 22. (E-F) Chest CT scan showed remarkably improved pleural effusion and pulmonary infiltrates on Oct 31. 
extractable nuclear antigen (ENA) screening were positive for antibodies to Sm, SSA and U RNP. The anti-ribosomal P-protein antibody and antiRo-52 antibody were also positive, but anti-double stranded DNA, anti-SSB, anti-Scl-70, anti-Jo1 , anti-centromere protein $\mathrm{B}$, anti-histone, antinucleosome and anti-cardiolipin antibodies were all negative. $\mathrm{C} 3$ complement was $0.65 \mathrm{~g} / \mathrm{L}$ (normal: $0.8 \sim 1.6 \mathrm{~g} / \mathrm{L}$ ) and C4 was $0.05 \mathrm{~g} / \mathrm{L}$ (normal: $0.1 \sim 0.4$ $\mathrm{g} / \mathrm{L})$. Twenty-four hour urinary protein excretion was $360 \mathrm{mg} / 24$ hours (normal: $0 \sim 120 \mathrm{mg} / 24$ hours). A thoracocentesis was performed and the pleural fluid obtained was an exudate (Table 1). No bacteria, fungi or anaerobes grew in throat swab, peripheral blood, ascitic and pleural fluid cultures. A SLE flare was suspected considering that the patient had polyserositis, lymphocytopenia, hypocomplementemia and positive ANA, Sm and SSA. Thereafter, the patient was treated with $40 \mathrm{mg} /$ day of methylprednisolone, $0.2 \mathrm{~g} /$ day of oral hydroxychloroquine and supportive management. Seven days later, her abdominal pain and distension markedly improved. On October 31, a CT scanning of the abdomen and chest showed marked improvements in ascites, pleural effusion, pulmonary infiltrates, and bowel wall edema and thickening (Figure 1E-F and 2E-F).

The patient was discharged from our hospital on November 2 and then followed up at the outpatient clinic. A combination of $10 \mathrm{mg} /$ day of prednisolone and $0.2 \mathrm{~g} /$ day of oral hydroxychloroquine was used as her maintenance medication. One month later, she remains free from symptoms, with no detectable ascites and pleural fluid, and without any evidence of recurrence at the time of this writing.

\section{Discussion}

The reported patient had massive and painful ascites of rapid-onset as her prominent manifestation of a SLE flare in the absence of other wellrecognized clinical features for SLE and common causes for ascites. Moreover the patient had widespread abdominal pain, a phenomenon usually due to an acute abdomen or abdominal infection. An extensive investigation showed that the patient had normal cardiovascular and hepatic function and discarded acute abdomen, abdominal infection, tuberculous peritonitis and peritoneal malignan- cy. Urinalysis showed proteinuria, but there were no elevation of blood urea nitrogen, oliguria or anuria, and twenty-four hour urinary protein collection was less than $500 \mathrm{mg} / 24$ hours. Thus, her ascites was most probably due to acute LP and not related to the mild renal dysfunction. In addition, the serum level of CA125 was markedly increased. There are reports of CA125 elevation in SLE patients. Compared with patients with normal values, those with elevated CA 125 had significantly more serositis and lung involvement $t^{4,5}$.

The pathogenesis of LP is still not entirely clear but it is generally considered to be associated with a vasculitis of the peritoneum. Immune complex deposition and complement activation are two critical triggering factors that have been suggested ${ }^{6}$. These factors may cause a vessel hyperpermeability ${ }^{7-9}$, resulting in the formation of an exudate.

Although we could not obtain a peritoneal biopsy in our case, diffuse bowel wall edema and thickening were noted on the abdominal CTscan. Gastrointestinal infection is probably the most common cause of bowel wall thickening and usually diagnosed clinically. Some bacterial causes include Escherichia coli, Shigella, Salmonella, Yersinia and Campylobacter ${ }^{10}$. Viral causes include Rotavirus, Herpes, Cytomegalovirus and EpsteinBarr virus ${ }^{10,11}$. In addition, pulmonary infiltrates occur as a manifestation of active SLE and are difficult to distinguish from secondary pulmonary infection on imaging studies. In the present case, the patient did not have fever, diarrhea, cough and chest pain and the microbial cultures were all negative. Thus, her effusions were most probably due to SLE and not related to gastrointestinal and respiratory infections. When gastrointestinal involvement is associated with SLE activity, the edema and thickening of bowel wall is considered a characteristic sign of lupus mesenteric vasculitis ${ }^{12}$. Since the bowel wall and mesentery are both covered by peritoneum, this finding strongly suggests the presence of LP. Furthermore, autoantibodies and low levels of complement were detected in the serum of this patient. Finally, the massive ascites and severe abdominal pain responded dramatically to steroid therapy. Therefore, ascites in this case was most probably caused by LP resulting from immune complex deposition and complement activation in the peritoneum.

According to the literature, non-steroidal anti-inflammatory drugs (NSAIDs) ${ }^{13}$, antimala- 
rials $^{3,14}$ and immunosuppressive drugs including glucocorticoids $s^{3,15-17}$, azathioprine ${ }^{15,18}$ and cyclophosphamide ${ }^{19}$ have been used in the management of LP-associated ascites. Patients usually respond well to steroids ${ }^{16,17}$. Antimalarial agents are generally used as an adjunct to other treatments for SLE, such as NSAIDs and glucocorticoids ${ }^{20}$.

In conclusion, this case highlights that acute LP should be considered in the differential diagnosis of recent onset of painful ascites when no common causes for ascites are found, especially in patients with SLE. Experience with our patient indicates that adrenal steroids and hydrocychloroquine treatment may be effective for this rare but severe manifestation of SLE flare.

\section{References}

1. Bulkley BH, Roberts WC. The heart in systemic lupus erythematosus and the changes induced in it by corticosteroid therapy. A study of 36 necropsy patients. Am J Med 1975; 58: 243-64.

2. Brigden W, Bywaters EG, Lessof MH, Ross IP. The heart in systemic lupus erythematosus. Br Heart J 1960; 22: 1-16.

3. Prasad S, Abujam B, Lawrence A, Aggarwal A. Massive ascites as a presenting feature of lupus. Int $\mathrm{J}$ Rheum Dis 2012; 15: e15-6.

4. Szekanecz E, Szucs G, Szekanecz Z, Tarr T, AntalSzalmás P, Szamosi S, et al. Tumor-associated antigens in systemic sclerosis and systemic lupus erythematosus: associations with organ manifestations, immunolaboratory markers and disease activity indices. J Autoimmun 2008; 31: 372-6.

5. Yang Z, Liang Y, Li C, Zhong R. Serum CA125 elevation is independently associated with serositis in SLE patients. Clin Exp Rheumatol 2012; 30: 93-8.

6. Kageyama Y, Yagi T, Miyairi M. Systemic lupus erythematosus associated with massive ascites and pleural effusion in a patient who presented with disseminated intravascular coagulation. Intern Med 2002; 41: 161-6.

7. Lister KJ, James WG, Hickey MJ. Immune complexes mediate rapid alterations in microvascular permeability: roles for neutrophils, complement, and platelets. Microcirculation 2007; 14: 709-22.
8. Kuroyanagi T, Kura K, Arao T. The presence of new permeability factor in serum of patients with systemic lupus erythematosus and its significance. Tohoku J Exp Med 1978; 124: 47-56.

9. Jacob A, Hack B, Chiang E, GarciaJG, QuiggRJ, Alexander JJ. C5a alters blood-brain barrier integrity in experimental Lupus. FASEB J 2010; 24: 1682-8.

10. d'Almeida M, Jose J, Oneto J, Restrepo R. Bowel wall thickening in children: CT findings. Radiographics 2008; 28: 727-46.

11. Tamura S, Maruyama D, Miyagi Maeshima A, Taniguchi H, Kakugawa Y, Mori M, et al. Epstein-Barr virusassociated enteropathy as a complication of infectious mononucleosis mimicking peripheral T-cell lymphoma. Intern Med 2013; 52: 1971-5.

12. Tian XP, Zhang X. Gastrointestinal involvement in systemic lupus erythematosus: insight into pathogenesis, diagnosis and treatment. World J Gastroenterol 2010; 16: 2971-7.

13. Man BL, Mok CC. Serositis related to systemic lupus erythematosus: prevalence and outcome. Lupus 2005; 14: 822-6.

14. Pott Júnior H, Amate Neto A, Teixeira MA, Provenza JR. Ascites due to lupus peritonitis: a rare form of onset of systemic lupus erythematosus. Rev Bras Reumatol 2012; 52: 116-9.

15. Kaklamanis P, Vayopoulos G, Stamatelos G, Dadinas G, Tsokos GC. Chronic lupus peritonitis with ascites. Ann Rheum Dis1991; 50: 176-7.

16. Ishiguro N, Tomino Y, Fujito K, Nakayama S, Koide H. A case of massive ascites due to lupus peritonitis with a dramatic response to steroid pulse therapy. Jpn J Med 1989; 28: 608-11.

17. Türkçapar N, Ozyüncü N, Cinar K, Ensari A, Küçük O, Idilman $\mathrm{R}$, et al. A case of systemic lupus erythematosus presenting with protein-losing enteropathy. Turk J Gastroenterol 2006; 17: 226-30.

18. Mier A, Weir W. Ascites in systemic lupus erythematosus. Ann Rheum Dis 1985; 44: 778-9.

19. Bitran J, McShane D, Ellman MH. Arthritis Rounds: Ascites as the major manifestation of systemic lupus erythematosus. Arthritis Rheum 1976; 19: 782-5.

20. Dubois EL. Antimalarials in the management of discoid and systemic lupus erythematosus. Semin Arthritis Rheum 1978; 8: 33-51. 